\title{
Co-Constructing Inquiry-Based Science with Teachers: Essential Research for Lasting Reform
}

\author{
Carolyn W. Keys, Lynn A. Bryan \\ Science Education Department, 212 Aderhold Hall, University of Georgia, Athens, \\ Georgia 30602-7126
}

Received 25 October 1999; accepted 21 December 2000

\begin{abstract}
In this article we assert a potential research agenda for the teaching and learning of science as inquiry as part of the JRST series on reform in science education. Drawing on the theoretical frameworks of cognitive and sociocultural constructivism, cultural models of meaning, the dialogic function of language, and transformational models of teacher education, we propose that more research is needed in the areas of teachers' beliefs, knowledge, and practices of inquiry-based science, as well as, student learning. Because the efficacy of reform efforts rest largely with teachers, their voices need to be included in the design and implementation of inquiry-based curriculum. As we review the literature and pose future research questions, we propose that particular attention be paid to research on inquiry in diverse classrooms, and to modes of inquiry-based instruction that are designed by teachers. (๑) 2001 John Wiley \& Sons, Inc. J Res Sci Teach 38: 631-645, 2001
\end{abstract}

Today's reform rhetoric has revived the concept of inquiry as representing the essence of science education. Reform documents such as the National Science Education Standards are promoting inquiry as the "central strategy for teaching science." The editors of the Journal of Research in Science Teaching have encouraged dialogue on the efficacy of programs, such as inquiry-based science, that are being initiated or implemented in our schools. The editors state, "this reform effort represents unfinished business for the science education community. Despite the seeming efficacy of the goals and claims that underlie current reform, there has been little formal, scholarly effort on the part of the science education community to ground the reform carefully in research." As part of a series of articles in JRST that explore the relationship between research and reform, this article discusses the need for research on the topic of inquiry. The purpose of this article is to propose a direction for future research on inquiry that places teacher knowledge, actions, and meanings for inquiry-based science at the center of the reform process. The proposal of a research agenda for inquiry approaches that are centered on teacher beliefs and knowledge may accelerate the production of a research literature that bridges the theory-practice gap in this important area. In this article, we present the position that additional

Correspondence to: C.W. Keys; E-mail: ckeys@coe.uga.edu 
research is needed in four major domains: (a) teacher beliefs about inquiry; (b) the teacher knowledge base for implementing inquiry; (c) teacher inquiry practices; and (d) student science learning from teacher-designed, inquiry-based instruction, including conceptual knowledge, reasoning, and nature of science understandings. As we discuss each of these domains, we will call particular attention to the need for research in two thematic strands that cut across the domains: (a) the need for research in culturally diverse classrooms; and (b) the need for research on inquiry-based instruction that has been designed by teachers rather than researchers or is truly collaborative with teachers contributing at least as much to the instructional design as researchers.

\section{What Is Inquiry-Based Instruction?}

The National Science Education Standards [National Research Council (NRC), 1996] represent the current consensus of the science education community on the role of inquiry-based instruction in science. The Standards suggest that students in K-12 science classrooms develop both "abilities necessary to do scientific inquiry" and "understandings of scientific inquiry" (NRC, 1996, p. 121). Abilities to do scientific inquiry include: identifying and posing questions, designing and conducting investigations, analyzing data and evidence, using models and explanations, and communicating findings. Understandings include a knowledge of how scientists conduct their work and concepts related to the nature of science. The Standards further suggest that inquiry-based instruction will be a powerful vehicle for students to learn scientific content. Whereas the Standards offer several examples of inquiry-based instruction, they do not give specific prescriptions for how to conduct inquiry in the classroom, so that teachers can create modes of inquiry that fit their local classroom situations.

We support the idea that teachers are intelligent decision makers who will have their own perspectives on and definitions of inquiry. The Standards provide important suggestions for the goals of inquiry teaching, content for inquiry learning, and some examples of the kinds of activities in which students may be engaged. However, it will be up to classroom teachers to formulate patterns of teaching actions that accomplish these goals. Teaching actions will necessarily differ based on factors in the local environment, such as teacher knowledge, student age, student language proficiency, etc. Therefore, our stance is that inquiry is not a specific teaching method or curriculum model, although it may be embedded within or overlap various models, such as the learning cycle or conceptual change. Multiple modes and patterns of inquirybased instruction are not only inevitable but also desirable because they will paint a rich picture of meaningful learning in diverse situations. Multiple modes of inquiry teaching and learning will invite teachers to engage in participating in inquiry in ways that match their own beliefs and teaching styles.

\section{Relevant Theoretical Frameworks}

We suggest that four theoretical frameworks are appropriate for conducting research on teacher beliefs, knowledge, and practice of inquiry including, coordination of cognitive constructivist and sociocultural constructivist frameworks, cultural models of meaning, dialogic models of language, and transformational models of teaching reform. These four theoretical frameworks may be used individually or in combination to guide research across the four domains and two strands of research on inquiry mentioned in the introduction. Although a variety of methodologies that might be appropriate for any particular study may be derived from these frameworks, we believe the most fitting include naturalistic, interpretive, ethnographic, case, dialectical, hermeneutic, and phenomenological methodologies. 


\section{Coordination of Cognitive and Sociocultural Constructivism}

Building a framework for a research program on teachers' beliefs about inquiry involves a coordination of cognitive constructivist and sociocultural perspectives (Cobb, 1994). Research on teacher thinking, including teachers' content and pedagogical knowledge and beliefs about inquiry, stems from cognitive constructivism (von Glasersfeld, 1989). From a cognitive constructivist perspective, knowledge is not independent of the knower; knowledge is understanding physical and abstract objects in our experience. For example, there is not one true definition of inquiry waiting to be discovered, but an understanding of inquiry is constructed by individual participants. According to von Glasersfeld (1996), knowledge is adaptive; the worth of knowledge is not determined by its degree of truth, but by its viability. Those forms of knowledge about inquiry which are viable in classroom practice will become constructed forms of inquiry. For children, knowledge about science will be an individual construction through participation in the social and physical environment of the classroom.

Like many other scholars (Cobb, 1994; Eisenhart, Finkel, \& Marion, 1996; Gergen, 1995; O’Loughlin, 1992; Richards, 1995; Shotter, 1995), we believe that a cognitive constructivist framework is helpful but incomplete in that it does not account for social and cultural influences on learning. Science education research has historically emanated from a constructivist perspective that is cognitive in its orientation-that of Piagetian or radical constructivism (Eisenhart et al., 1996). Although a cognitive constructivist perspective focuses on what students learn and the processes by which they come to know (Cobb, 1994; von Glasersfeld, 1996), it fails to acknowledge "the structural characteristics of schooling or science, the social organization of instruction, the tools of language and inquiry that motivate what teachers and students do in school and in science, or the identities that school science inspires" (Eisenhart et al., 1996, p. 278). A sociocultural lens can be applied to research on inquiry-based instruction by examining how teachers implement inquiry within the cultural context of their local situations, and how tools, language, and social organizations are used by teachers and interpreted by students. Studies of how students appropriate and use tools during inquiry-based instruction, how they negotiate meaning with peers, and how they form science identities would add to the knowledge base on the value of inquiry. A sociocultural lens applies to both influences on the participants in research studies, as well as the contextual, collaborative, and social organization of the research itself. Working collaboratively with teachers will necessitate taking into account cultural factors in their environment, including constraints to inquiry such as time and resources.

\section{Cultural Models of Meaning}

A sociocultural perspective allows researchers to focus on the meaning making function of discourse in the local context. According to Gee (1990), social and cultural understandings lie at the heart of making meaning as humans attempt to understand the language of others. Beliefs and values fall into patterns that involve assumptions and choices about meaning based upon simplified models of the world. Gee described these cultural models as "something like movies or videotapes in the mind" (Gee, 1990, p. 78) that represent idealized or typical realities. Humans react to language and actions based on their cultural models. Cultural models therefore necessarily affect communication in the classroom, as teachers and students interact together. Similarly, cultural models affect researchers' and teachers' understandings of classroom instruction and reform initiatives. The construct of cultural models informs research by framing the work in authentic communication among researchers, students, and teachers. 
For example, Olson (1981) researched the dilemmas created when curriculum designers imposed reform-oriented science curricula on secondary science teachers in Canada. He reported that the teachers found the language of the curriculum, which was couched in the jargon of cognitive psychology, to be a foreign language. Olson, recognizing the imperative for mutual understanding, called for the construction of a common language between teachers and university researchers as a basis for institutionalizing meaningful reform almost two decades ago:

The growth of this language is a dialectical process. ... Innovators can begin to understand how their ideas and language map onto the world of teachers; where there is a need for translation and where there are unrealistic assumptions. The language of the new practice is thus carefully mapped onto the actual working lives of teachers; neither the adequacy of the new ideas, nor the inadequacy of the old are assumed. Dialectically, each is used to assist the other. (Olson, 1981, pp. 272-273)

\section{Dialogic Function of Language}

Closely related to ideas of developing a mutual language based on overlapping cultural models is the construct of the dialogic function of language. In a recent interpretation, Wertsch and Toma (1995), building upon the work of Vygotsky, Bahktin, and Lotman, illustrated how discourse in a Japanese classroom is dominated by the dialogic function of language in contrast to a univocal function. A univocal function of language often seen in American classrooms is to transmit information in a unidirectional mode. A dialogic function, in contrast, invites the recipient to respond and promotes thinking, questioning, and extension. Those teachers and students engaged in dialogic discourse treat utterances as thinking devices to generate and extend knowledge and the dialogic discursive style is considered to be necessary for the social construction of knowledge. A dialogic perspective may frame researchers' interpretations of teachers' interactions with their students, as well as researchers' interactions with teachers.

Also relevant is the writing of Lijnse (1995), who advocated a developmental research approach. Lijnse's ideas about developmental research are grounded in a theoretical construct that mirrors the ideas of cultural models of language, a dialectic process of language development, and a dialogic function of language in generating knowledge as described above. Lijnse elaborated on Davidson's notion of a "principle of charity," the idea that good teaching depends upon understanding that students' language about science makes sense to them, is based on good faith, and is the necessary starting place for communicating about science. Communication with students implies really listening to their explanations, not simply dismissing their ideas as incorrect if they do not match our conceptions. With the principle of charity as a guide, Lijnse recommended that science educators spend time in the development, implementation, and evaluation of reform-based practices in the local context. Communication and exchange of locally developed theories may then be shared and commonalties explored.

\section{Transformational Model of Teaching Reform}

A transformational model of science teaching reform should be applied that includes elements such as recognizing the importance of teacher beliefs, acknowledging that teachers will experience tensions in the change process, encouraging teacher reflection, and creating interactive environments for fostering conceptual connections (Bryan \& Abell, 1999; Parke \& 
Coble, 1997). There is a strong literature base for applying the construct of teacher beliefs to research on inquiry. Pajares (1992), reviewing the literature, asserted that beliefs are "the best indicators of the decisions individuals make throughout their lives" (p. 307). Beliefs structures play a major role in teacher decision making about curriculum and instructional tasks (Nespor, 1987; Pajares, 1992; Richardson, 1996). Nespor (1987) asserted that teachers rely on their core belief systems rather than academic knowledge during decision making because educational environments are ill-structured, not lending themselves to step-by-step problem solving. We agree with Richardson that teaching actions or practices represents one aspect of an entire belief system and that interview and observation research is a reflective, iterative process that encompasses the belief system as a whole. A research agenda on teacher beliefs about inquiry should recognize the integral relationship between beliefs and actions.

Reviewing the Literature and Recognizing Gaps

\section{Teacher Beliefs}

Research on teacher thinking indicates that teachers are active curriculum creators who make instructional decisions based on a complex system of beliefs and knowledge (Bryan \& Abell, 1999; Clanindin \& Connelly, 1992). In general, teachers' beliefs influence (a) knowledge acquisition and interpretation, (b) defining and selecting the task at hand, (c) interpretation of course content, and (d) choice of assessment (Clark, 1988; Nespor, 1987; Pajares, 1992; Richardson, 1996). When reform efforts are based on documents that represent the intended curricula of researchers rather than the enacted curricula of teachers, there is a mismatch that impedes science education reform (Lynch, 1997; Prawat, 1992). The literature has often shown that curriculum reforms, however well meaning, are shaped and altered by teachers' beliefs and understandings of the local context (Bryan, 1998; Brickhouse \& Bodner, 1992; Cronin-Jones, 1991; Wallace \& Wildy, 1995).

Nespor's (1987) framework for teacher beliefs suggests that they are episodic (based on story), affective (value laden), and are built on existential presumptions (making abstract attributes such as ability real entities). These elements of a belief system may significantly affect how teachers implement inquiry-based instruction. Teacher beliefs about students and learning, such as ability levels or the need for drill and practice, represent obstacles to inquiry-based instruction. Cronin-Jones (1991) conducted two case studies of middle-grade teachers implementing a constructivist-based curriculum and found that both teachers held strong beliefs that science is a body of factual content and that students did not have the necessary skills for autonomous learning. These beliefs led to teaching practices that were at variance with the intended curriculum.

Similarly, teachers' beliefs about the nature of science as an objective body of knowledge created by a rigid "scientific method" (Brickhouse, 1990; Duschl \& Wright, 1989; Gallagher, 1991) impede their teaching of an accurate view of inquiry. Teachers with a more contemporary and accurate understanding of the nature of science tend to implement a more problem-based approach to science teaching (Brickhouse, 1990). Hashweh (1996) characterized science teachers as learning constructivists, learning empiricists, knowledge constructivists, and knowledge empiricists. He found that differences in epistemological beliefs influenced classroom teaching actions. Learning and knowledge empiricists did not recognize students' prior knowledge, believed in reinforcement as a method of learning, and emphasized the scientific method both as a paradigm for scientists and for instruction. Learning and knowledge constructivists, on the 
other hand, did seek and recognize prior knowledge and used a wider variety of teaching strategies to promote the construction of conceptual understandings. Thus, research indicates that teacher beliefs have an important role in both planning and teaching actions.

Tobin and colleagues described teacher beliefs as cultural myths that impede reform (Tobin $\&$ McRobbie, 1996). Tobin and McRobbie identified four major myths of secondary science instruction, including the transmission myth, the efficiency myth, the myth of rigor, and the myth of preparing students for examinations. A secondary chemistry teacher in their study viewed himself simultaneously as a powerful keeper and transmitter of chemistry knowledge, and as a relatively powerless individual in terms of transforming the chemistry curriculum. Beliefs about transmission, efficiency, rigor, and exam preparation are pervasive in the high school culture, and research on promoting inquiry-based instruction in this environment must take these cultural beliefs into consideration. Recent research on teachers who have an interest in inquiry at the high school level indicates that teachers have both personal and cultural belief sets regarding inquiry (Keys \& Kang, 2000). Teachers hold personal beliefs that inquiry promotes the scientific thinking and learning autonomy they want for their students; yet, enacting inquiry is mediated by cultural beliefs, such as transmission and efficiency. These dual belief sets cause tension for teachers who are attempting to use inquiry-based instruction.

As yet, we have little knowledge of teachers' views about the goals and purposes of inquiry, the processes by which they carry it out, or their motivation for undertaking a more complex and often difficult to manage form of instruction. A few classroom case studies (Carnes, 1997; Crawford, 1998; Flick, 1995; Fradd \& Lee, 1999; Keys \& Kennedy, 1999) indicate that teachers do form individualized conceptions of inquiry and use it as a referent for science teaching in ways that may not match the conceptions of university researchers. For example, Carnes (1997) found that urban middle school teachers viewed open debate of ideas as a major element of inquiry. Elementary teachers have been observed to have students generate portions of their investigations, such as raising questions, selecting variables, or interpreting data, while using all class instruction to guide the rest of the process (Flick, 1995; Fradd \& Lee, 1999; Keys \& Kennedy, 1999). Keys \& Kennedy reported that an experienced fourth-grade teacher seized opportunities for inquiry spontaneously when she allowed students to deviate from planned instruction to pursue authentic questions.

In summary, there is a large body of research indicating that teacher beliefs about the nature of science, student learning, and the role of the science teacher substantially affect planning, teaching, and assessment. If teachers are responsible for implementing and sustaining the vision of reform set forth by documents such as the National Science Education Standards (NRC, 1996), they must have a legitimated and empowered role in developing the knowledge to facilitate change. Several recent case studies have reported positive efforts of collaborating with teachers who are implementing innovative classroom practices guided by science education reform initiatives. For example, in a study conducted by Ben-Chaim, Joffe, and Zoller (1994), teachers took an active role in the decision making and planning of science curriculum innovation and in determining the goals of their science instruction. The researchers attributed the resonance between the intended and enacted curricula to the "full active participation of the teachers involved in the decision-making process associated with curricular reform" (p. 365). Similar success in bringing the intended curriculum in closer resonance to the enacted curriculum occurred in studies by Lynch (1997), Parke and Coble (1997), Tobin, Briscoe, and Holman (1990), and Tobin and LaMaster (1995). In those studies, collaborative reflection in the research relationship was portrayed as a means of empowering teachers to examine their beliefs and make changes to their practice to be more congruent with reform initiatives. We conclude that more research is needed on the beliefs of teachers who are implementing inquiry-based 
instruction, especially in diverse settings, as well as studies of reflection on beliefs and change as teachers work collaboratively on inquiry with researchers in local settings.

\section{Teachers' Knowledge Base for Implementing Inquiry}

The research on teacher knowledge used in inquiry-based instruction may be the least developed of the four domains we discuss in this article. It seems intuitive that teachers who use an inquiry approach must have rich and deeply developed understandings of science content, student learning, the nature of science, and ways to engage students in investigative practices. A recent study by Crawford (2000) provides insights into the beliefs, practices, and pedagogical content knowledge related to teaching ecology. She reported that six themes characterized the teaching of Jake, a veteran high school teacher, including situating instruction in authentic contexts, grappling with data, collaboration between students and teacher, connections with society, teacher modeling behavior of a scientist, and the development of student ownership. Several critical incidents of practice illustrate how Jake perceived of and implemented these characteristics in teaching. For example, Jake spent a good portion of the class period discussing anomalies in the data (bacterial counts) and used the opportunity to teach nature of science ideas, including authentic problems, collaboration, and modeling scientific work. Crawford concluded that inquiry-based teaching requires a high level of pedagogical content knowledge, including a deep understanding of the nature of science and complex understandings of how to coach, mentor, and collaborate with students. More studies such as this one are necessary to elucidate the knowledge base required for inquiry teaching, which may be used to inform teacher education programs.

Studies of teachers using inquiry-based approaches and their change stories in diverse settings will be an extremely valuable addition to the knowledge base. The painting of portraits of inquiry-in-action in a variety of diverse settings is greatly needed. This is particularly important in science, in which previous inquiry curriculum interventions of minimal impact were based on the dominant European-American male interpretations of doing science as inquiry. The local culture of the classroom [affluent learners, diverse learners, single-sex classrooms, inclusion students, English as a Second Language (ESL) students, etc.] will have a significant role in the interpretation of inquiry practice. A research agenda on inquiry teaching might include illuminating new perspectives on inquiry (feminist, ethnic-cultural, etc.). For example, Fradd and Lee (1999) investigated teachers' understanding of science teaching and inquiry in classrooms where English is a second language for children from Hispanic and Haitian cultures. They reported that teachers are reluctant to move away from more structured strategies that, in their experience, are effective for students from diverse cultures. However, they pointed out that such a reluctance may limit students from realizing their potential in scientific thinking. Fradd and Lee asserted that the argument posturing teacher-as-knowledge-transmitter versus teacher-asfacilitator is not a productive mode of discourse in diverse settings. The solution to the argument will be an integration of teacher roles derived from student needs in the local context. Fradd and Lee concluded, "In addressing the needs of diverse learners, a research agenda that includes the perspectives of teachers as contributors can provide an important focus. Teachers provide important insights unavailable from any other sources" (1999, p. 19). We agree that practicing teachers offer perspectives on teaching and learning that are not available even from extended observational studies of researchers. Teachers have an intimate knowledge of their own students; and because they are accountable for their students' learning and well-being in the classroom, only they can resolve all of the competing influences on what is enacted in the classroom. Studies of teacher knowledge, including pedagogical content knowledge, nature of science knowledge, 
curriculum knowledge, and student knowledge, will be essential for developing preservice and inservice education for inquiry.

\section{Teacher Practices}

Some recent studies of teacher beliefs have also reported on teacher inquiry practices (Carnes, 1997; Crawford, 2000; Keys \& Kennedy, 1999; Keys \& Kang, 2000). However, an important source of information on teacher practices has come from the writings of teachers themselves. Several elementary teachers most often participating in research groups with the focus of exploring their own practice have contributed book chapters or even entire books describing how they perceive of and implement inquiry (Doris, 1991; Gallas, 1995; Iwasyk, 2000; Kurose, 2000; Kwan, 2000; Nissley, 2000; Pearce, 1993, 1999; Reardon, 1993; Schmidt, 1993; Whitin \& Whitin, 1997). One of the most important themes emerging from this work is that these teachers overwhelmingly practiced inquiry-based instruction as arising from students' authentic questions. Their inquiry teaching narratives included rich descriptions of activities they used to help students generate questions, or how they used discussion to shape children's natural questions into topics for investigation. For example, Doris (1991) stimulated curiosity with guinea pig observations and turned children's questions back over to them to answer themselves. Pearce (1999) kept a question board throughout the year so that students could write whatever questions occurred to them at any time. He also used observation and question generation activities, "Question Search," and "More Testable Questions," to coach his students into asking questions that they might actually investigate. Whitin and Whitin (1997) described a yearlong inquiry project on bird behavior initiated by children's own questions about the birds they saw. Gallas (1995) devoted time not only to question posing, but also to extensive discourse on young children's questions in which various theories and supporting evidence are posed. It is clear that these teachers value student questioning as central to the inquiry experience.

A second theme emerging from elementary teachers' practices is that of integrating science with language education. Teachers link science inquiry with reading and literature, as well as using inquiry as a springboard for a variety of types of writing, including journals, observations, and creative stories (Nissley, 2000; Pearce, 1993; Reardon, 1993). Third, elementary teacher inquiry practices include establishing a collaborative community of scientists. A significant part of inquiry is meeting to discuss science ideas, progress, and findings. Saul's (1993) collaborative inquiry group established the Kids' Inquiry Conference; individual teachers have established their own cultures of scientific discourse practice, including Scientists Meeting (Reardon, 1993), Class Meetings (Doris, 1991), and Science Talks (Gallas, 1995). Whitin and Whitin (1997) based their yearlong bird behavior project on evolving questions and discussions of the children as the project continued. These teachers modeled the scientific community expertly in their own classrooms.

The rich descriptions of inquiry-based practices noted above are an excellent resource for teachers desiring to initiate inquiry, as well as researchers seeking to learn more about how inquiry is enacted in the classroom. We perceive three major areas of research on inquiry-based practices that need further research. One includes studies similar to those described above from middle school and high school. The sociocultural context of middle school and high school will provide both broader opportunities and, at the same time, more perceived constraints for implementing inquiry in the classroom. Broader opportunities might arise from students' increased domain knowledge and cognitive skills; yet constraints such as time and the mandated curriculum represent serious barriers to inquiry. High school teachers' beliefs about curriculum constraints have been reported to influence their inquiry practices (Keys \& Kang, 2000). More 
studies are needed indicating how inquiry may be practiced in a variety of different subject areas. For example, the study by Crawford (2000) illustrated inquiry practices in a specialized class, ecology, rather than the typical biology, chemistry, physics, or general science curriculum. More studies in typical science classrooms may enhance the transferability of research results to other settings. Furthermore, science classes that are aimed at technical degree students rather than college-bound students may reveal new approaches to inquiry-based practices.

Second, more studies of inquiry-based practices are needed in diverse cultural settings. Whereas some of the classrooms mentioned above may be diverse in nature, there is little discussion of how inquiry is shaped to meet students' cultural or individual learning needs. Would students from an urban classroom be able to study birds, for example? How do resources, including the nature of the community, affect inquiry practices? Finally, studies of student learning from teacher-designed inquiry-based instruction are needed. What conceptual, problem-solving, and nature of science understandings result from a student participating in Pearce's or Doris's class? The need for more research on student learning from inquiry-based instruction is addressed in detail below.

\section{Student Learning from Inquiry-Based Instruction}

Three major bodies of contemporary research (post-1980s) have explored student learning from inquiry-based instruction, including the performance of students on what are traditionally known as the science process skills, the uses of inquiry in promoting conceptual change, and recent studies of student learning in classrooms where researcher-designed, inquiry-based instruction is taking place. Each of these research areas and remaining gaps will be discussed below.

Research on the Science Process Skills. One area of contemporary research on inquiry is related to children's understanding and use of science process skills in designing investigations. This research approach is based on the presumption that scientific inquiry is a cognitively complex process requiring that learners have background knowledge in the scientific concept they plan to investigate, ask appropriate questions, identify and operationalize variables, formulate hypotheses, and design clear experiments (Germann, Aram, \& Burke, 1996). Most research in this paradigm attempts to isolate and identify specific reasoning skills that promote and prevent children from doing experiments as scientists would do them. Frequently, research findings indicate that children of about age 11 are skilled in observing phenomena, recording data, and identifying the effects of a single independent variable on a dependent variable. However, when faced with more complex concepts such as continuous versus categorical variables or drawing meaningful inferences from the data, students exhibit difficulty and much poorer performance (DeTure, Fraser, \& Doran, 1995; Duggan, Johnson, \& Gott, 1996; Gott \& Duggan, 1995). For example, Varelas (1997) found that third- and fourth-grade students were able to appreciate that they would find different results with repeated trials in experiments, but could not conceive of a theoretically perfect result and best representative measure. Metz (1995) argued that research fails to support the contention that there are developmental limitations to children's ability to reason scientifically. She asserted that young students should not be relegated to concrete activities, but engaged in all aspects of inquiry. We agree with Metz that decontextualizing inquiry investigations into discrete process skills prohibits synthesizing and elaborating scientific knowledge, as well as causing motivational problems. 
Duggan et al. (1996) insightfully suggested that pupil failure to design rigorous investigations to generate evidence may result from lack of experience and understanding about the entire concept of investigation. Without motivation or understanding of why they are collecting data, children may not strive to produce clear results. In our view, a weakness of this avenue of research is the measurement of children's investigative skills against those of professional scientists. It may not be profitable to research the state of children's reasoning skills against a scientific ideal when interpretive research indicates that children have different purposes, meanings, and modes of engagement for inquiry activities than do scientists (Rath \& Brown, 1996). For example, Keys (1998) found that 11-year-old children often choose to undertake descriptive investigations that document natural phenomena when given choices about what they wish to investigate, rather than experimental investigations. There is a clear need for research on student learning from inquiry-based instruction in which the questions, purposes, and data of the investigations make sense to the students who are engaging in investigation.

Inquiry in Relation to Conceptual Change Teaching and Learning. Social constructivist orientations to learning science have led several scholarly groups to research the impact of inquiry instruction within a conceptual change approach for science teaching and learning (Driver, Asoko, Leach, Mortimer, \& Scott, 1994). The role of inquiry in such an approach is to provide evidence that will convince learners to change their science ideas within a context for social discourse. Inquiry activities are carefully crafted to demonstrate how children's previous ideas may not account for observed phenomena, such as growing plants with no soil (Roth \& Rosaen, 1991); lighting bulbs in a series (Magnusson, Templin, \& Boyle, 1997); or showing how light rays travel long distances (Driver et al., 1994). Studies of conceptual change curriculum interventions have been shown to be effective for promoting the building and modification of children's ideas toward scientifically acceptable viewpoints. For example, Fellows (1994), reporting on the effectiveness of curriculum developed by Anderson and colleagues, found that sixth-grade students (a) added new principles or theories to their conceptual schema, (b) organized their schema around more central concepts, and (c) moved closer to scientific understandings. Her study indicated that all 25 students in the class were successful in adding new concepts to their knowledge structures, and that 20 of 25 students were successful in understanding target concepts related to difficult subject matter on molecular movement. Similarly, Palincsar, Anderson, and David (1993) reported that about 51\% of sixth-grade students in their study could provide a scientific explanation for the effects of variables on dissolving when guided collaborative problem solving was combined with students designing their own inquiry procedures. Recently, Ford, Palincsar, and Magnusson (2000) demonstrated sophisticated understandings of light developed by fourth-grade students using a combination of guided inquiry and specially designed texts.

Despite these promising findings of conceptual change approaches to teaching and learning used by researchers, we have little evidence about how practicing teachers are using conceptual change models in their own classrooms. Research is needed to show how reformoriented classroom teachers adopt, create, or modify conceptual change instruction to fit their own local circumstances. Sample questions include: How widespread is a conceptual change, inquiry-based approach to teaching science? What does conceptual change, inquirybased learning look like in a rural, poor urban, or ESL classroom? What do students learn about the nature of science from such a program of instruction? In addition, much of the literature cited above has occurred in elementary or middle school classrooms. There is a need for research on inquiry-based learning to support conceptual understanding at the secondary level. 
Research on Project-Based Science and Specially Designed Inquiry Curriculum. New studies on researcher-based interventions to promote inquiry provide promising results. For example, the ThinkerTools Inquiry Curriculum (White \& Frederiksen, 1998), incorporating rich inquiry-based instruction based on student generated questioning, experimentation with technological and real-life tools, model formulation, and metacognitive reflection, has shown dramatic improvements of middle school students' understanding of motion. White and Frederiksen (1998) reported that seventh- to ninth-grade students who had participated in the ThinkerTools curriculum outperformed high school physics students on qualitative problems involving real-world situations. Students who participated in the metacognitive reflection intervention achieved at even greater levels than those participating in the curriculum without the reflection. This intervention was particularly effective with low-achieving students. The authors conclude the curriculum has a strong potential to increase both conceptual understanding and understandings about inquiry, especially with low-socioeconomic status, urban students.

Krajcik and colleagues (Krajcik, Blumenfeld, Marx, Bass, \& Fredricks, 1998) investigated project-based, inquiry-oriented science in middle school classrooms. The researchers pointed out that much of the previous research on inquiry has been done in rich demonstration sites or in classes taught by the researchers, thereby limiting our understanding of how inquiry teaching and learning look in an ordinary classroom taught by teachers. Krajcik et al. reported on the various approaches to engagement, dialogues, questions, strengths, and limitations of students' learning in an open-inquiry environment. Like other researchers (Duggan \& Gott, 1995; Keys, 1998), they noted students' positive engagement with the inquiry tasks and success in setting up meaningful experiments, as well as limitations in their understandings of the meaning of data, and the relationships among data, evidence, and conclusions. They suggested that more research is needed on instructional strategies that promote productive project-based science.

We applaud Krajcik and colleagues' effort to understand the complex nature of instruction in the ordinary classroom. However, the curriculum undertaken by the teachers was designed by the researchers rather than the teachers themselves, limiting our understanding of how teachers conceive and practice project-based inquiry instruction. Similar collaborative projects were undertaken by Lehrer, Carpenter, Schauble, and Putz (2000) and Roseberry, Warren, and Conant (1992), in which approaches initiated and designed by researchers were collaboratively implemented with the expertise of teachers in their classrooms. Although these studies show promising results in terms of student engagement and learning, we reiterate that more research is needed on teacher-designed approaches to inquiry-based instruction, as well as teacher-designed adaptations of curriculum to their own unique situations. As with the conceptual change research, most new inquiry interventions have been implemented at the elementary and middle school levels. Little research on inquiry-based instruction has been conducted at the high school level. Studies of learning from inquiry-based approaches in the secondary classroom are necessary in light of the difficulties conducting inquiry in the more constraining high school environment.

\section{Conclusion}

In summary, although much has been written about reform, research on the role and knowledge of teachers in the reform process has been minimal (Kyle, 1994). To underscore this point, Kyle quoted Anderson and Mitchener: "The big advances in understanding about student learning have not been matched by equivalent advances in understanding about teaching. How to teach under real world conditions in such a manner as to foster this kind of learning is not as well 
understood as learning per se" (p. 36). Research on the roles and knowledge of teachers in implementing inquiry in the classroom will have a broad impact on science education because such studies will reflect what may be realistically accomplished on a large scale. In this article we have proposed a research agenda to collect vital data on teacher beliefs, knowledge, practices, and student learning from teacher-designed inquiry instruction, especially in diverse settings. These data are needed to inform the science education community, teachers, administrators, teacher educators, and the public as a whole about what kinds of inquirybased science may be reasonably carried out in ordinary classrooms and what kinds of student learning outcomes can be reasonably expected. Only then will we be able to evaluate the efficacy of inquiry as a teaching and learning tool in science.

As Hiller stated, teachers' voices have typically been silent in the reform process:

National agendas, such as Project 2061, Scope Sequence and Coordination, were not touching my daily life. I knew about them, had worked on some, and then, like my students, dismissed them. Good people were trying to create a new world of science literacy, but they were not viable options in my teaching life because they were not grounded in any relevancy for my students and me. Our voices were silent in the process, as my students' voices used to be silent in my classroom. (Hiller, 1995, p. 64)

Only when the voices of researchers are in resonance with the voices of teachers can we begin to create harmonized reform-based instruction that is enduring. We hope that teachers' once muted voices will be raised loudly and clearly in the call to reform.

\section{References}

Ben-Chaim, D., Joffe, N., \& Zoller, U. (1994). Empowerment of elementary school teachers to implement science curriculum reforms. School Science and Mathematics, 94, 356-366.

Brickhouse, N.W. (1990). Teachers' beliefs about the nature of science and their relationship to classroom practice. Journal of Teacher Education, 41, 53-62.

Brickhouse, N.W., \& Bodner, G.M. (1992). The beginning science teacher: Classroom narratives of convictions and constraints. Journal of Research in Science Teaching, 29, $471-$ 485.

Bryan, L. (1998, April). Learning to teach elementary science: A case of teacher beliefs about science teaching and learning. Paper presented at the National Association for Research in Science Teaching, San Diego, CA.

Bryan, L.A., \& Abell, S.K. (1999). The development of professional knowledge in learning to teach elementary science. Journal of Research in Science Teaching, 36, 121-139.

Carnes, G.N. (1997, March). Teacher conceptions of inquiry and related teaching practices. Paper presented at the annual meeting for the National Association of Research in Science Teaching, Chicago, IL.

Clanindin, D.J., \& Connelly, F.M. (1992). Teacher as curriculum maker. In P. Jackson (Ed.), The handbook of research on curriculum (pp. 363-396). New York: Macmillan.

Clark, C. (1988). Asking the right questions about teacher preparation: Contributions of research on teacher thinking. Educational Researcher, 17, 5-12.

Cobb, P. (1994). Where is the mind? Constructivist and sociocultural perspectives on mathematical development. Educational Researcher, 23, 13-20.

Crawford, B.A. (1998, April). Creating and sustaining an inquiry-based classroom: A different view of teachers' work. Paper presented at the annual meeting for the National Association of Research in Science Teaching, San Diego, CA. 
Crawford, B.A. (2000). Embracing the essence of inquiry: New roles for science teachers. Journal of Research in Science Teaching, 37, 916-937.

Cronin-Jones, L.L. (1991). Science teacher beliefs and their influence on curriculum implementation: Two case studies. Journal of Research in Science Teaching, 28, 235-250.

DeTure, L.R., Fraser, B.J., \& Doran, R.L. (1995). Assessment and investigation of science laboratory skills among year 5 students. Research in Science Education, 24, 253-266.

Doris, E. (1991). Doing what scientists do. Portsmouth, NH: Heinnemann.

Driver, R., Asoko, H., Leach, J., Mortimer, E., \& Scott, P. (1994). Constructing scientific knowledge in the classroom. Educational Researcher, 23, 5-12.

Duggan, S., Johnson, P., \& Gott, R. (1996). A critical point in investigative work: Defining variables. Journal of Research in Science Teaching, 33, 461-474.

Duschl, R.A., \& Wright, E. (1989). A case study of high school teachers' decision making models for planning and teaching science. Journal of Research in Science Teaching, 26, 467501.

Eisenhart, M., Finkel, E., \& Marion, S. (1996). Creating the conditions for scientific literacy: A reexamination. American Educational Research Journal, 33, 261-296.

Fellows, N.J. (1994). A window into thinking: Using student science writing to understand conceptual change in science learning. Journal of Research in Science Teaching, 31, 985-1001.

Flick, L.B. (1995). Navigating a sea of ideas: Teachers and students negotiate a course toward mutual relevance. Journal of Research in Science Teaching, 32, 1065-1082.

Ford, D.J., Palincsar, A.S., \& Magnusson, S.J. (2000, April). The role of text in supporting and extending first-hand investigations in guided inquiry science: An example for a fourth grade study of light. Paper presented at the annual meeting of the National Association for Research in Science Teaching, New Orleans, LA.

Fradd, S.H., \& Lee, O. (1999). Teachers' roles in promoting science inquiry with students from diverse language backgrounds. Educational Researcher, 28, 14-20.

Gallagher, J.J. (1991). Prospective and practicing secondary school science teachers' beliefs about the philosophy of science. Science Education, 75, 121-133.

Gallagher, J.J., \& Richmond, G. (1999). Stimulating discourse on science education reform: An editorial and call for papers. Journal of Research in Science Teaching, 36, $753-$ 754.

Gallas, K. (1995). Talking their way into science. New York: Teachers College Press.

Gee, J.P. (1990). Social linguistics and literacies: Ideology in discourses. Bristol, PA: Taylor and Francis.

Gergen, K.L. (1995). Social construction and the educational process. In L.P. Steffe \& J. Gale (Eds.), Constructivism in education (pp. 17-40). Hillsdale, NJ: Erlbaum.

Germann, P.J., Aram, R., \& Burke, G. (1996). Identifying patterns and relationships among the responses of seventh-grade students to the science process skill of designing experiments. Journal of Research in Science Teaching, 33, 79-99.

Gott, R., \& Duggan, S. (1995). Investigative work in the science curriculum. Bristol, PA: Open University Press.

Hashweh, M.Z. (1996). Effects of science teachers' epistemological beliefs in teaching. Journal of Research in Science Teaching, 33, 47-63.

Hiller, N.A. (1995). The battle to reform science education: Notes from the trenches. Theory Into Practice, 34, 60-65.

Iwasyk, M. (2000). Kids questioning kids: "Experts sharing." In J. Minstrell \& E.H. van Zee (Eds.), Inquiring into inquiry learning and teaching in science (pp. 130-138). Washington, DC: American Association for the Advancement of Science. 
Keys, C.W. (1998). A study of grade six students generating questions and plans for openended investigations. Research in Science Education, 28, 301-316.

Keys, C.W., \& Kang, N.H. (2000, April). Secondary science teachers' beliefs about inquiry: A starting place for reform. Paper presented at the annual meeting of the National Association for Research in Science Teaching, New Orleans, LA.

Keys, C.W., \& Kennedy, V. (1999). Understanding inquiry science teaching in context: A case study of an elementary teacher. Journal of Science Teacher Education, 10, 315-333.

Krajcik, J., Blumenfeld, P.C., Marx, R.W., Bass, K.M., Fredricks, J., \& Soloway, E. (1998). Inquiry in project-based science classrooms: Initial attempts by middle school students. Journal of the Learning Sciences, 7, 313-350.

Kurose, A. (2000). Eyes on science: Asking questions about the moon on the playground, in class and at home. In J. Minstrell \& E.H. van Zee (Eds.), Inquiring into inquiry learning and teaching in science (pp. 139-147). Washington, DC: American Association for the Advancement of Science.

Kwan, R. (2000). Tapping into children's curiosity. In J. Minstrell \& E.H. van Zee (Eds.), Inquiring into inquiry learning and teaching in science (pp. 148-150). Washington, DC: American Association for the Advancement of Science.

Kyle, W.C. (1994). School reform and the reform of teacher education: Can we orchestrate harmony? Journal of Research in Science Teaching, 31, 785-786.

Lehrer, R., Carpenter, S., Schaubble, L., \& Putz, A. (2000). Designing classrooms that support inquiry. In J. Minstrell \& E.H. van Zee (Eds.), Inquiring into inquiry learning and teaching in science (pp. 80-99). Washington, DC: American Association for the Advancement of Science.

Lijnse, P.L. (1995). "Developmental research" as a way to an empirically based "didactical structure" of science. Science Education, 79, 189-199.

Lynch, S. (1997). Novice teachers' encounter with national science education reform: Entanglements or intelligent interconnections? Journal of Research in Science Teaching, 34, 3-17.

Magnusson, S.J., Templin, M., \& Boyle, R.A. (1997). Dynamic science assessment: A new approach for investigating conceptual change. Journal of the Learning Sciences, 6, 91-142.

Metz, K.E. (1995). Reassessment of developmental constraints on children's science instruction. Review of Educational Research, 65, 93-127.

National Research Council. (1996). The National Science Education Standards. Washington, DC: National Academy Press.

Nespor, J. (1987). The role of beliefs in the practice of teaching. Journal of Curriculum Studies, 19, 317-328.

Nissley, C. (2000). Giving children a chance to investigate according to their own interests. In J. Minstrell \& E.H. van Zee (Eds.), Inquiring into inquiry learning and teaching in science (pp. 151-156). Washington, DC: American Association for the Advancement of Science.

O'Loughlin, M. (1992). Rethinking science education: Beyond Piagetian constructivism toward a sociocultural model of teaching and learning. Journal of Research in Science Teaching, $29,791-820$.

Olson, J. (1981). Teacher influence in the classroom: A context for understanding curriculum translation. Instructional Science, 10, 259-275.

Pajares, M.F. (1992). Teachers' beliefs and educational research: Cleaning up a messy construct. Review of Educational Research, 62, 307-332.

Palincsar, A.S., Anderson, C., \& David, Y.M. (1993). Pursuing scientific literacy in the middles grades through collaborative problem solving. Elementary School Journal, 93, $643-658$. 
Parke, H.M., \& Coble, C.R. (1997). Teachers designing curriculum as professional development: A model for transformational science teaching. Journal of Research in Science Teaching, 34, 773-789.

Pearce, C. (1993). What if . . ? In W. Saul (Ed.), Science workshop: A whole language approach. Portsmouth, NH: Heinnemann.

Pearce, C.R. (1999). Nurturing inquiry. Portsmouth, NH: Heinnemann.

Rath, A., \& Brown, D.E. (1996). Modes of engagement in science inquiry: A microanalysis of students' orientations toward phenomena at a summer science camp. Journal of Research in Science Teaching, 33, 1083-1097.

Reardon, J. (1993). Developing a community of scientists. In W. Saul (Ed.), Science workshop: A whole language approach. Portsmouth, NH: Heinnemann.

Richards, J. (1995). Construct[ion/iv]ism: Pick one of the above. In L.P. Steffe \& J. Gale (Eds.), Constructivism in education (pp. 57-64). Hillsdale, NJ: Erlbaum.

Richardson, V. (1996). The role of attitudes and beliefs in learning to teach. In J. Sikula (Ed.), Handbook of research on teacher education (pp. 102-119). New York: Macmillan.

Roseberry, A.S., Warren, B., \& Conant, F.R. (1992). Appropriating scientific discourse: Findings from language minority classrooms. Journal of the Learning Sciences, 2, 61-94.

Roth, K.J., \& Rosaen, C.L. (1991, April). Writing activities in a conceptual change science learning community: Two perspectives. Paper presented at the annual meeting of the National Association for Research in Science Teaching, Lake Geneva, Switzerland.

Schmidt, A. (1993). "When lava lets loose": A science workshop heats up. In W. Saul (Ed.), Science workshop: A whole language approach. Portsmouth, NH: Heinnemann.

Shotter, J. (1995). In dialogue: Social constructionism and radical constructivism. In L.P. Steffe \& J. Gale (Eds.), Constructivism in education (pp. 41-56). Hillsdale, NJ: Erlbaum.

Tobin, K., Briscoe, C., \& Holman, J.R. (1990). Overcoming constraints to effective elementary science teaching. Science Education, 74, 409-420.

Tobin, K., \& LaMaster, S.U. (1995). Relationships between metaphors, beliefs, and actions in a context of science curriculum change. Journal of Research in Science Teaching, 32, 225 242.

Tobin, K., \& McRobbie, C.J. (1996). Cultural myths as constraints to the enacted science curriculum. Science Education, 80, 223-241.

Varelas, M. (1997). Third and fourth graders' conceptions of repeated trials and best representatives in science experiments. Journal of Research in Science Teaching, 34, 853-872.

von Glasersfeld, E. (1989). Cognition, construction of knowledge, and teaching. Synthese, $80,121-140$.

von Glasersfeld, E. (1996). Introduction: Aspects of constructivism. In C.-T. Fosnot (Ed.), Constructivism: Theory, perspectives, and practices (pp. 3-7). New York: Teachers College Press.

Wertsch, J., \& Toma, C. (1995). Discourse and learning in the classroom: A sociocultural approach. In L. Steffe \& J. Gale (Eds.), Constructivism in education (pp. 185-225). Hillsdale, NJ: Erlbaum.

White, B., \& Frederiksen. (1998). Inquiry, modeling, and metacognition: Making science accessible to all students. Cognition \& Instruction 16, 3-118.

Whitin, P., \& Whitin, D.J. (1997). Inquiry at the window. Portsmouth, NH: Heinnemann.

Wildy, H., \& Wallace, J. (1995). Understanding teaching or teaching for understanding: Alternative frameworks for science classrooms. Journal of Research in Science Teaching, 32, $143-156$. 